\title{
ИНТРАЛИНГВИСТИЧКИ ПРИСТУП У ИЗУЧАВАҢУ ИМПЕРФЕКАТСКИХ ОБЛИКА У КЛАСИЧНОМ И МОДЕРНОМ ГРЧКОМ ЈЕЗИКУ 1
}

Употреба аугмента и у класичном и модерном грчком језику је истоветна. Као деиктичку партикулу -е, која се јавља као секундарни показатељ прошлих времена трајних и тренутних глагола, у раду ћемо приказати врсте аугмента у оба језика. Наше истраживање указаће да се највећа подударност у употреби аугмента између класичног и модерног грчког налази управо код силабичкої аугмента $\varepsilon-$. Контрастирање одређених граматичких форми и прављење корелације између класичног и модерног грчког језика, доприноси успешнијем савладавању фундаменталних језичких процеса у савременом грчком језику. Опште је место да контрастирањем језичких система постижемо боље разумевање и савладавање одређених граматичких категорија неког циљног језика. Стога је битно указати на важност прављења корелације језичких феномена у домену интра- и интерлингвистичких истраживања. Контрастирање језичких феномена истовремено унапређује когнитивне способности самих студената и представља значајан мотивациони фактор у процесу учења, посебно на пољу екстринзичке мотивације. Као предложак за наше истраживање, анализирали смо основне карактеристике имперфекатских облика класичног и савременог грчког језика и њихово превођење на српски језик.

Кључне речи: контрастивна анализа, имперфекат, класични грчки језик, модерни грчки језик., аугмент.

* Филолошки факултет БУ, Катедра за неохеленске студије, Студентски трг 3 , 11000 Београд. Mailto vojkans@hotmail.com.

** Филолошки факултет БУ, Катедра за неохеленске студије, Студентски трг 3, 11000 Београд. Mailto aelakovic@yahoo.com.

*** Овај рад израђен је у оквиру пројекта Језищи и кулйуре у времену и йросйору, број 178002, који финансира Министарство просвете и науке Републике Србије.

1 Рад изложен на Петом међународном конгресу Примењена линівисииика gанас

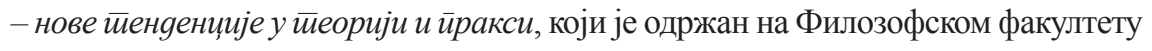
Универзитета у Новом Саду од 27-29. новембра 2015. године. 


\section{1. Уводна разматрања}

У нашем раду бавићемо се контрастирањем имперфекатских облика и њихове употребе у класичном и модерном грчком језику. Наша анализа ће обухватити следеће аспекте истраживања:

- основне карактеристике у грађењу и употреби имперфекта у класичном и модерном грчком;

- изучавање античког наслеђа које се очувало у модерном грчком језику, пре свега, у погледу силабичког и темпоралног аугмента, као и неких класичних имперфекатских облика који су присутни и у данашњем говорном језику;

- $\quad$ контрастирање одређеног корпуса класичних и савремених облика глагола у имперфекту и њихово адекватно превођење на српски језик;

- значај контрастивних језичких истраживања и њихов доринос бољем разумевању и савладавању одређених граматичких категорија у савременој језичкој едукацији.

Имајући у виду сличности које се појављују унутар имперфекатских облика, морамо напоменути да оне представљају директно наслеђе преузето из класичног грчког језика у модерном грчком. И класични и модерни грчки језик творе ово време од презентске основе и одређених глаголских наставака, уз додавање аугмента, било силабичког, било темпоралног. Имперфекат се са класичног и модерног грчког језика на српски, преводи нашим пређашњим несвршеним временом или глаголима трајног значења у прошлом времену и означава радњу која је трајала, или се понављала у прошлости (Holton, Mackridge, Warburton, 2004: 121; Тријандафилидис, 1995: 181).

Аугмент представља показну (деиктичку) партикулу -e, која се у класичном грчком језику јавља у свим лицима индикатива историјских времена ${ }^{2}$ (Meillet, 1950; Rix, 1976). У модерном грчком, аугмент представља директно наслеђе из класичног грчког језика (Mackridge, 1985; Thomson, 1989). Функција овог наглашеног префикса била је да означи темпоралну или локалну удаљеност. У локалној

2 Аугмент се не јавља ни у српском ни у латинском језику, док је поред грчког, посведочен још и у индоиранском, јерменском и фригијском (грч. е̌ стинд. ábharat, јерм. eber, фриг. غ̇ $\delta \alpha \varepsilon \varsigma)$. 
ИНТРАЛИНГВИСТИЧКИ ПРИСТУП У ИЗУЧАВАҢУ ИМПЕРФЕКАТСКИХ ОБЛИКА У КЛАСИЧНОМ И МОДЕРНОМ ГРЧКОМ ЈЕЗИКУ

функцији појављује се код оних показних заменица које показују

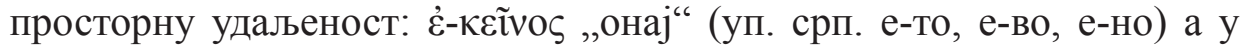
темпоралној функцији јавља се код аугмента који показује временску удаљеност. Некада је функција аугмента била јако важна тако да је он носио главни тон, док је сами глаголски облик био ненаглашен, па су се тако аугмент и глаголски облик стопили у једну реч, нпр. ह̇ $\lambda \varepsilon \gamma о \mathrm{v}$ „говорах“ од $\lambda \dot{\varepsilon} \gamma \omega$ „говорим““ (Будимир, Црепајац, 1979: 117).

\section{2. Аугмент у класичном и модерном грчком језику}

Употреба аугмента и у класичном и модерном грчком је истоветна, дакле, аугмент је деиктичка партикула -е, која се јавља као секундарни показатељ прошлих времена трајних и тренутних глагола. Зависно од почетног гласа глаголске основе у класичном грчком, он може бити силабички или темпорални. Аугмент се у класичном језику задржава у свим лицима индикатива имперфекта, аориста и плусквамперфекта, док се у модерном грчком аугмент јавља само када је наглашен и то у 1,2 . и 3 . лицу сингулара и 3 . лицу плурала (Тријандафилидис, 1995: 186, Warburton, 1973 ). Дакле, поштујући правило по којем је акценат у облицима имперфекта увек на трећем слогу од краја, као и правило да се аугмент увек задржава када је наглашен (Warburton, 1973), аугмент је сувишан у 1. и 2. лицу плурала (1. л. сг. $\varepsilon ́ \gamma \rho \alpha \varphi \alpha$, али 1. л. пл. $\gamma \rho \alpha ́(\varphi \alpha \mu \varepsilon)$. Овде је важно напоменути да аугмент и у класичном грчком повлачи акценат што даље од краја речи, али за разлику од модерног грчког, он задржава аугмент у свим облицима, без обзира на број слогова унутар основе или наставка. Такође, употреба аугмента је била факултативна у индоевропском језику, а та слобода у његовој употреби датира још из времена пре Хомера, код ког такође, уочавамо ту појаву. У класичном периоду аугмент се често изоставља код плусквамперфекта. У којни се, међутим, аугмент јавља чак и у конјунктиву (Будимир, Црепајац, 1979: 120).

\section{3. Силабички аугмент}

У класичном грчком језику имамо поделу аугмента на силабич$\kappa и$ и $\overline{и е м и ̆ о р а л н и, ~ д о к ~ у ~ м о д е р н о м ~ г р ч к о м ~ ј е з и к у, ~ п о с т о ј е ~ т р и ~ в р с т е ~}$ 
аугмента: силабички, иеемйорални (који се још назива и фонейским) и унуширашњи аугмент. Слоготворно в́- се јавља у функцији аугмента код глаголских основа које почињу консонантом. Највећа подударност у употреби аугмента између класичног и модерног грчког налази се

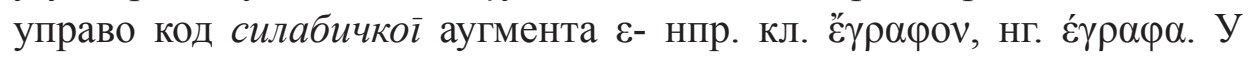
модерном грчком, глаголи који почињу сугласником у индикативу имперфекта и аориста, такође, добијају испред основе једно е-, које се у одређеним случајевима задржава или изоставља. У класичном грчком, овај аугмент се јавља поред имперфекта и аориста, још и у плусквамперфекту и то, у свим лицима индикатива ових времена, без обзира на број слогова унутар једног облика, док у модерном грчком аугмент изостаје у првом и другом лицу плурала индикатива аориста и имперфекта актива. Иако је основно правило у употреби силабичког аугмента да он долази код глагола који почињу консонантом, ипак и у класичном и модерном грчком постоје неки изузеци у његовој употреби. Тако на пример, класични грчки бележи појаву темпоралног аугмента уместо силабичког, и то код глагола: $\mu \varepsilon \dot{\varepsilon} \lambda \omega-$ импф. й $\mu \varepsilon \lambda-$

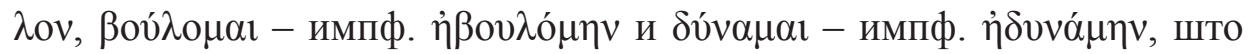
није случај када су новогрчки глаголи у питању. С друге стране, у модерном грчком такође, постоје неки изузеци у употреби силабичког аугмента, напр. када желимо да избегнемо неку нејасноћу, као и због

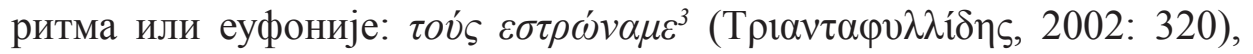
потом следи једна мања група глагола која уместо $\varepsilon$ - добијају аугмент

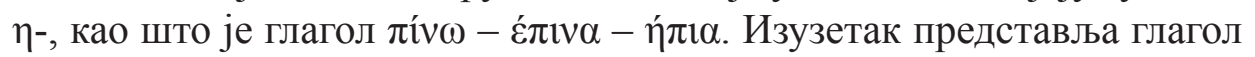
„знати“ који има исти облик и за аорист и за имперфекат: $\xi \dot{\varepsilon} \rho \omega-\eta ́ \xi \varepsilon \rho \alpha$

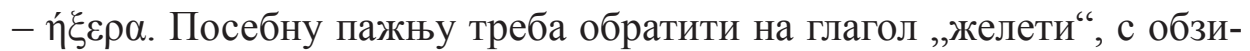
ром на то да ненативни говорници модерног грчког често мешају облике индикатива аориста актива и имперфекта актива: $\theta \varepsilon \dot{\lambda} \omega-\theta \varepsilon \dot{\lambda} \eta \sigma \alpha$

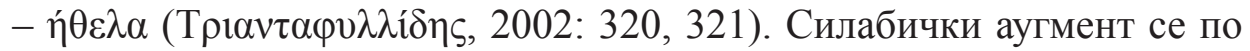
правилу јавља код двосложних глагола, тј. код оних глагола код којих су и основа и наставак једносложни. Међутим, постоји и неколицина једносложних глагола која у аористу немају аугмент, као што је: $\beta \gamma \alpha i ́-$

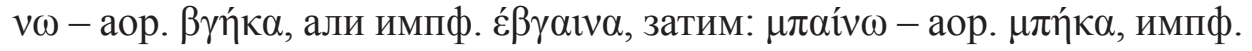

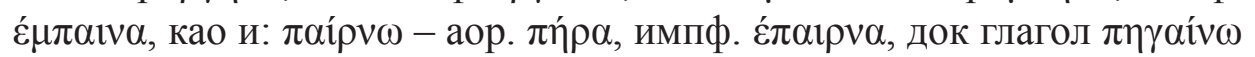

3 Овакве облике је могуће и данас сусрести у неким дијалектима новогрчког језика. 
нема аугмент ни у имперфекту ни у аористу: аор. $\pi \eta ́ \gamma \alpha$, импф. $\pi \eta ́ \gamma \alpha \iota v \alpha$ (Holton, Mackridge, Warburton, 2004: 152). Постоје случајеви када овај аугмент није наглашен и то у облицима индикатива пасивног аориста: $\varepsilon-\lambda \varepsilon \dot{\chi} \theta \eta, \varepsilon-\sigma \tau \alpha \dot{\lambda} \eta, \varepsilon-\rho \rho i ́ \varphi \theta \eta$ (Holton, Mackridge, Warburton, 2004: 152). Овде је реч о изразима који представљају директно наслеђе из катаpeвусе (Holton, Mackridge, Warburton, 2004: 152). У класичном грчком не постоје одступања у правилима када су у питању наведени глаголи и грађење њихових имперфекатских облика.

Подударност у употреби силабичког аугмента и у класичном и у модерном грчком јавља се и код глагола који су почињали спирантом. Тај се спирант налазио, после додавања аугмента, у интервокалском положају, па се стога губио, а аугмент се према фонетским правилима контраховао са радикалним вокалом, нпр. кл. है $\chi \omega$, основа $\boldsymbol{\sigma} \varepsilon \chi-$ импф.

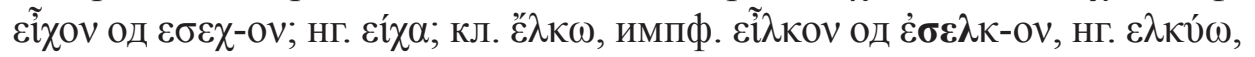
импф. $\varepsilon \dot{\imath} \lambda \kappa v \alpha^{4}$ (као и облик в́ $\left.\lambda \kappa v \alpha\right)$.

\section{4. Темпорални аугмент}

Темпорални аугмент у класичном грчком имају сви глаголи који почињу кратким вокалом или дифтонгом, без обзира да ли имају spiritus asper или lenis. Почетни вокал се сажима са аугментом у нов дуги вокал и то према одређеним правилима сажимања, тако што вокали:

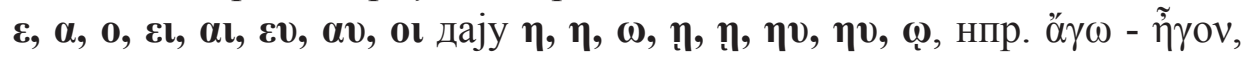

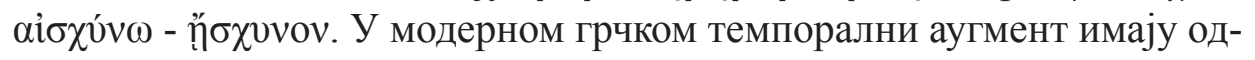
ређени глаголи који почињу са $\varepsilon, \alpha, \alpha$ и они почетку имају $\eta-$ као аугмент и задржавају га у свим временима. Два најчешћа примера ових глагола, који имају темпорални аугмент у индикативу имперфекта

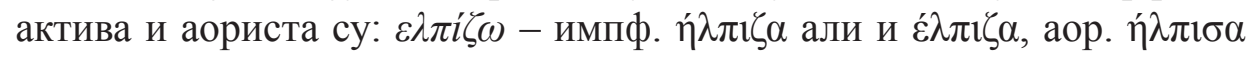
али и $\dot{\varepsilon} \lambda \pi 1 \sigma \alpha$, и глагол $\varepsilon \lambda \dot{\varepsilon} \gamma \chi \omega$ који у имперфекту може имати облике

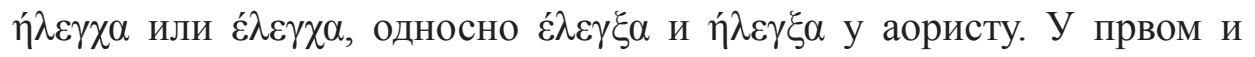
другом лицу плурала индикатива имперфекта, као и индикатива

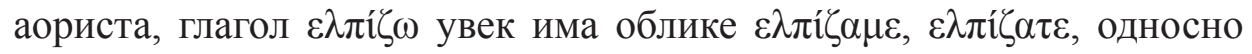
$\varepsilon \lambda \pi i ́ \sigma \alpha \mu \varepsilon, \varepsilon \lambda \pi i ́ \sigma \alpha \tau \varepsilon$ (Holton, Mackridge, Warburton, 2004: 152). У већи-

4 Код ових глаголских облика, губљењем интервокалске сигме у радикалном делу, према одговарајућем правилу, долази до контраховања силабичког аугмента у єเ- са почетним $\varepsilon$ испред кога је испало $-\sigma$. 
ни случајева, глаголи који почињу вокалом или дифтонгом задржа-

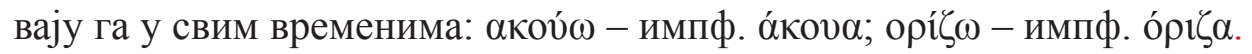
У класичном грчком једино дуги вокали као и дифтонг оv остају

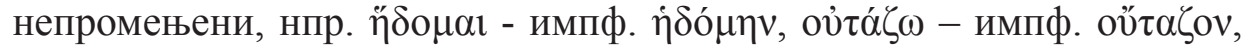
док сви остали почетни кратки вокали постају дуги у облицима са аугментом. Изузетак у модерном језику, такође, представљају и већ

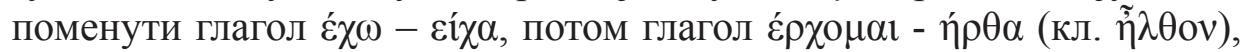

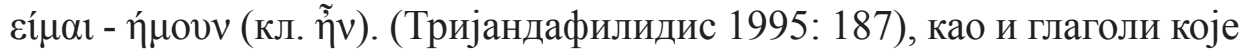
смо претходно поменули, а који уместо силабичког имају темпорални

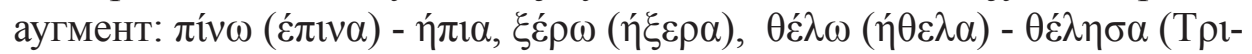
$\alpha v \tau \alpha \varphi v \lambda \lambda i ́ \delta \eta \varsigma, 2002: 320,321)$. Ови глаголи у класичном грчком имају силабички аугмент.

\section{5. Унутрашњи аугмент}

У граматикама новогрчког језика као трећи, засебан облик ауг-

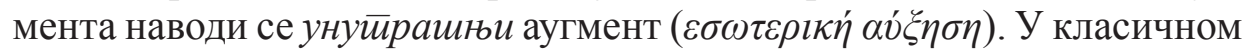
грчком овај трећи облик не постоји као посебна категорија аугмента. Заједничко код оба језика је што унутрашњи аугмент може бити силабички или темпорални, у зависности од тога да ли основа главног глагола почиње консонантом или вокалом, тј. дифтонгом. Овај аугмент долази код глагола који имају један или више предлога који служе у творби глагола као префикс. Оно што би требало посебно истаћи је чињеница, да ови префикси представљају директно наслеђе из античког грчког, иако се један број њих данас више не користе као предлози у модерном грчком. То су следећи предлози: $\alpha \mu \varphi t-, \alpha v \alpha-, \alpha v \tau t-$, $\alpha \pi 0-, \delta 1 \alpha-, \varepsilon 1 \varsigma_{-}, \varepsilon \kappa-,\left(\varepsilon \xi\right.$ пред вокалом) $\varepsilon v_{-}(\varepsilon \mu-$ испред лабијалног

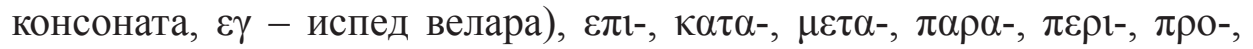
$\pi \rho \varsigma_{-}$, , $v v-,(\sigma v \mu-$ испред лабијалног консоната, бvү- испред велара, $\sigma v \lambda$ - испред $\lambda$ ), vлєр-, vло-. Предлози који се завршавају на вокал, губе

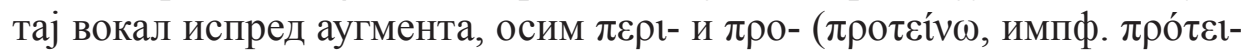

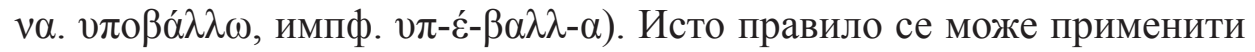
у класичном грчком, где се завршни вокал предлога сложених глагола

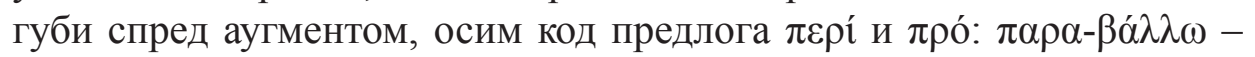

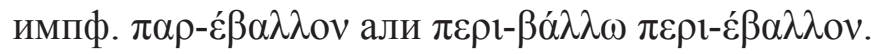

У модерном грчком, уколико аугмент није наглашен, онда се

он изоставља, нпр. vлоßа́ $\lambda \lambda \alpha \mu \varepsilon$, што није случај у класичном грчком, 
где он остаје током читаве промене: vлєßа́ $\lambda \lambda о \mu \varepsilon v$. Код неких глагола

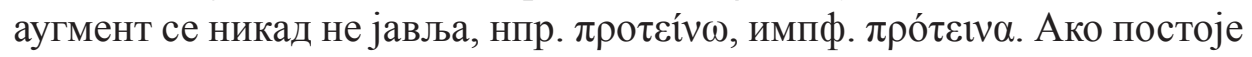
два предложна префикса, онда аугмент долази између другог предлога

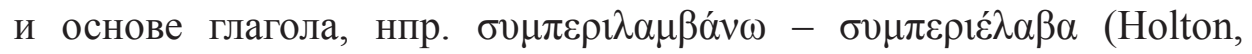
Mackridge, Warburton 2004: 153). У класичном такође вреди исто пра-

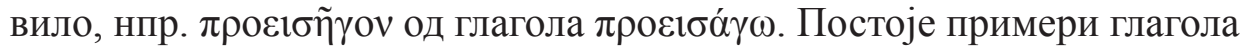
са предложним префиксом који мењају свој унутрашњи вокал основе

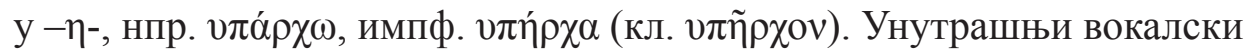

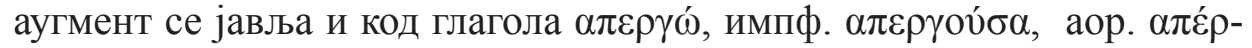

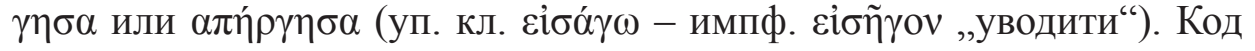
неких глагола јављају се оба облика: $\pi \alpha \rho \alpha \gamma \gamma \varepsilon ́ \lambda \lambda \omega$ аор. $\pi \alpha \rho \eta ́ \gamma \gamma \varepsilon \imath \lambda \alpha$ или $\pi \alpha \rho \alpha ́ \gamma \gamma \varepsilon \imath \lambda \alpha$ (Holton, Mackridge, Warburton, 2004: 153).

\section{6. Имперфекат у класичном и модерном грчком језику}

Главна обележја савременог грчког језика формирала су се већ пре петнаестог века. По Р. Браунингу, „из периода турске владавине нема фонолошких промена које би се могле уочити, мада су се оне несумњиво одигравале у процесу дијалекатске диференцијације“ (Браунинг, 2005: 115). Иако је у току развоја грчког језика било много промена у морфолошким обрасцима, они нису значајно умањили континуитет грчког језика, чији је глаголски систем у основи сачувао своју структуру и морфолошка обележја, за разлику од именског система који је претрпео многе промене (Браунинг, 2005: 11). Када је имперфекат у питању, постојала је узајамна интеракција

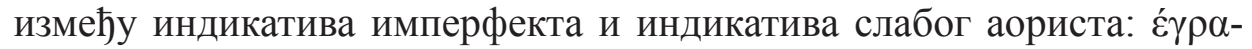
$\psi \varepsilon \varsigma$ „написао си“ и $\varepsilon^{\prime} \rho \alpha \varphi \varepsilon \varsigma$ једнако се срећу као аналошке творбе:

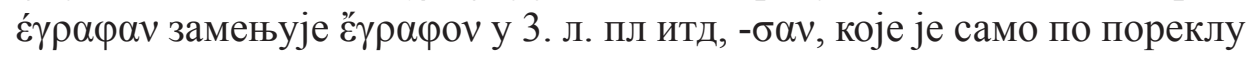
атичка иновација у атематским аористима, нагло се проширује у 3 . л. пл. и тако имамо облик вүра́фобаv (Браунинг, 2005: 41) .

Имперфекат се у класичном грчком гради од презентске основе, тематског вокала $(o, \varepsilon)$, секундарних личних наставака (актив: $-v,-\varsigma$, $-,-\mu \varepsilon v,-\tau \varepsilon,-v$; медиопасив: $-\mu \eta v,-\sigma o,-\tau o,-\mu \varepsilon \theta \alpha,-\sigma \theta \varepsilon,-v \tau о)$ и аугмента који може бити силабички или иеемиорални, у зависности од тога да ли основа глагола почиње са вокалом или консонантом. У модерном грчком, имперфекатски облици глагола 1. конјугације актива се граде 
такође од презентске основе, личних наставака за актив и аугмента

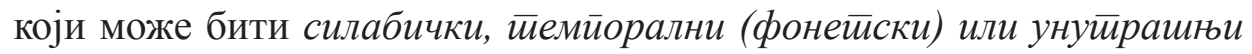
у зависности од тога да ли основа глагола почиње вокалом или консонантом $^{5}$. Имперфект глагола 2. конјугације се гради од презентске

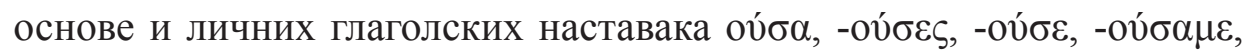

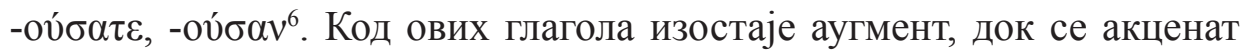

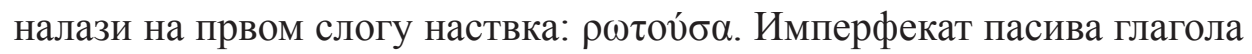

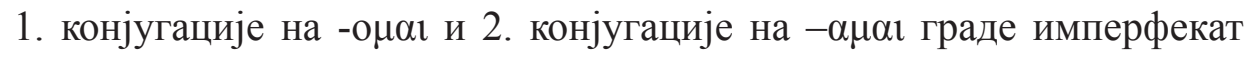
пасива од презентске основе и наставака $(-\operatorname{o\mu ovv}(\alpha),-\operatorname{o\sigma ovv}(\alpha)$, $-о \tau \alpha \nu(\varepsilon),-о \mu \alpha \sigma \tau \varepsilon,-о \sigma \alpha \sigma \tau \varepsilon,-о \nu \tau \alpha v,-о \mu \alpha \sigma \tau \alpha v,-о \sigma \alpha \sigma \tau \alpha v,-о v \tau \alpha \nu)$. За разлику од модерног грчког, имперфекат у класичном грчком гради своје облике правилно. Разлика у творби имперфекатских глаголских облика је и у томе што се класични грчки глаголи деле на две групе: глаголи $\omega$ и $\mu$ конјугације, док модерни грчки језик дели глаголске

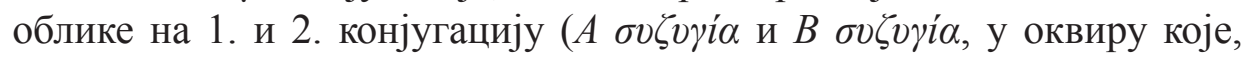

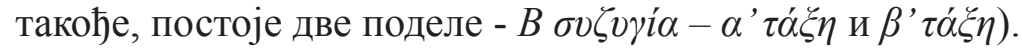

Ако поредимо употребу имперфекатских облика у класичном и модерном грчком и њихово адекватно превођење на српски језик, могу се уочити велике подударности у оба сегмента нашег истраживања. Имперфекат казује прошлу, несвршену радњу, која је трајала или се понављала у прошлости (Holton, Mackridge, Warburton, 2004:

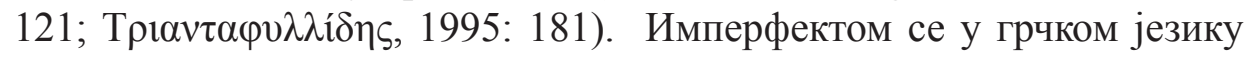

5 Имперфект глагола како 1. конјугације, тако и 2. конјугације гради се од презентске основе и личних глаголских наставака, специфичних не само за обе конјугације, већ и за два прошла времена, аорист и имперфекат $(-\alpha,-\varepsilon \varsigma$, $-\varepsilon,-\alpha \mu \varepsilon,-\alpha \tau \varepsilon,-\alpha v(\varepsilon))$. Акценат се у облицима имперфекта увек налази на трећем слогу од краја (пропарокситона). Код двосложних глагола 1. конјугације јавља се аугмент, као ознака за прошлу, свршену или несвршену радњу, напр. $\varepsilon-\gamma \rho \alpha \varphi-\alpha$ (од $\gamma \rho \alpha ́ \varphi \omega)$. Код тросложних и вишесложних глагола прве конјугације, као што смо рекли, не долази до појаве аугмента, већ се на презентску основу додају наведени наставци: $\delta 1 \alpha \sigma \kappa \varepsilon ́ \delta \alpha \zeta-\alpha$ (од $\delta 1 \alpha \sigma \kappa \varepsilon \delta \alpha ́ \zeta \omega)$. Треба нагласити да изузетак представљају глаголи $\alpha \kappa o v ́ \omega, \tau \rho \omega ́ \omega, \lambda \varepsilon ́ \omega, \kappa \lambda \alpha i ́ \omega, \varphi \tau \alpha i ́ \omega$ и каі́

6 Код глагола друге конјугације, без обзира на број слогова, имперфекат се гради од презентске основа и личних глаголских наставака $-\alpha,-\varepsilon \varsigma,-\varepsilon,-\alpha \mu \varepsilon$,

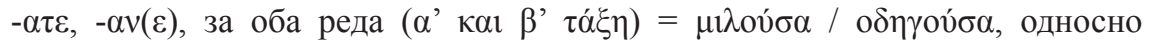
презентска основа и лични глаголски наставци $-\alpha,-\varepsilon \varsigma,-\varepsilon,-\alpha \mu \varepsilon,-\alpha \tau \varepsilon,-\alpha \nu(\varepsilon)$, само за други ред $\left(\beta^{\prime} \tau \alpha^{\prime} \xi\right)=\mu \dot{\imath} \lambda \alpha \gamma \alpha$. 
може изразити и радња која је трајала у прошлости и која је била прекинута неком другом, неочекиваном радњом која је у аористу. Такође, имперфектом можемо изразити две или више паралелних радњи у прошлости које су дуже или краће трајале. Користи се као:

a) imperfectum descriptivum, којим се описује неки прошли догађај:

\begin{tabular}{|c|c|c|}
\hline класични & 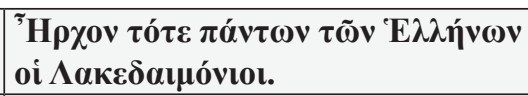 & $\begin{array}{l}\text { Лакеgемоњани су ш̄аgа влаgали } \\
\text { (влаgаху) свим Грицима. }\end{array}$ \\
\hline модерни & 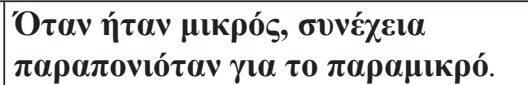 & $\begin{array}{l}\text { Каgа је био мали, сйално се } \\
\text { бунио за сваку сийнииу. }\end{array}$ \\
\hline
\end{tabular}

б) imperfectum iterativum, тзв. итеративни имперфект, којим се казује понављање радње у прошлости:

\begin{tabular}{|c|c|c|}
\hline класични & 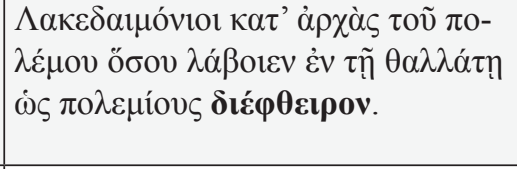 & 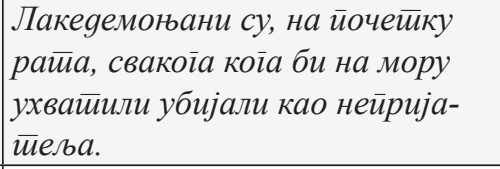 \\
\hline модерни & 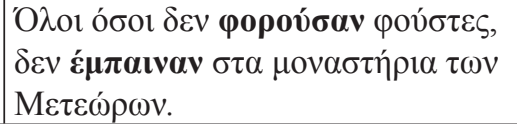 & 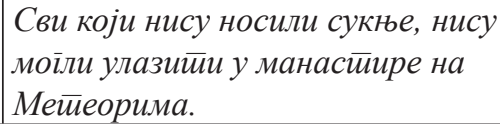 \\
\hline
\end{tabular}

в) imperfectum de conatu, којим се казује учестало започињање неке радње:

\begin{tabular}{|c|c|c|}
\hline класични & 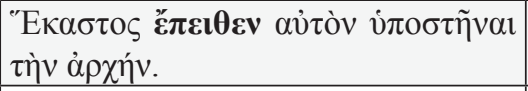 & $\begin{array}{l}\text { Сваки їа је йокушавао gа } \\
\text { наїовори gа йреузме власй. }\end{array}$ \\
\hline модерни & 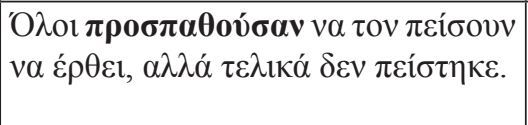 & $\begin{array}{l}\text { Сви су йокушавали gа їа убеgе } \\
\text { gа gође, али се на крају није gао } \\
\text { убеgийи. }\end{array}$ \\
\hline
\end{tabular}

Грчке облике имперфекта обично преводимо перфектом наших глагола трајног значења, нпр.:

\begin{tabular}{|c|c|c|}
\hline класични & 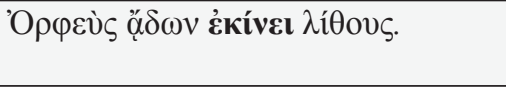 & $\begin{array}{l}\text { Oрфеј је иевајући покретао } \\
\text { камене. }\end{array}$ \\
\hline модерни & 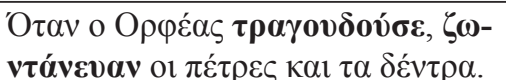 & $\begin{array}{l}\text { Када је Орфеј певао, камење и } \\
\text { дрвеће су оживљавали. }\end{array}$ \\
\hline
\end{tabular}




\section{7. Уместо закључка}

Имајући у виду све што је претходно наведено, потребно је још једном истаћи значај спровођења интралингвистичких истраживања и њихове примене унутар процеса језичке едукације. Контрастирање одређених граматичких форми и прављење корелације између класичног и модерног грчког језика, доприноси успешнијем савладавању фундаменталних језичких процеса у савременом грчком језику. Бројне анкете које смо спроводили на различитим годинама студија, потврђују нашу хипотезу да, усвајањем дела градива које се односи на имперфекат, студенти боље сагледавају облике и функцију овог времена у савременом грчком језику. Такође, уколико је објашњење одређених језичких феномена захтевало да они буду осветљени и са дијахронијског становишта, јављала се потреба да у сама предавања буду укључени и елементи историјске граматике грчког језика (Jovanović, 2012: 381).

Наша истраживања су показала да највећу корисност у савладавању грчког имперфекта студенти виде управо у делу градива које се односи на силабички и темпорални аугмент, стога смо највећу пажњу у раду посветили управо овом сегменту грађења грчког имперфекта 7 . Овакав начин успостваљања корелације у настави класичног и модерног грчког, у исто време представља проверу језичке компетенције наших студената и њихових когнитивних способности стечених у оквиру наставе модерног грчког језика (Brewster, 2004: 26-28). Поред методолошког, овакав приступ настави, укључује и мотивацијски аспект у оквиру наставног процеса, тим пре, што у складу са савременим тенденцијама у креирању мотивационих стратегија унутар наставног процеса, фактор мотивације представља један од кључних задатака поучавања (Vulfolk, Hjuz, Volkap, 2014: 321).

7 У настави модерног грчког језика, унутрашњи аугмент се обрађује на другој години студија, што се подудара са планом и програмом на класичном грчком језику, где се студенти упознавају са имперфекатским облицима, такође на другој години. 
ИНТРАЛИНГВИСТИЧКИ ПРИСТУП У ИЗУЧАВАҢУ ИМПЕРФЕКАТСКИХ ОБЛИКА У КЛАСИЧНОМ И МОДЕРНОМ ГРЧКОМ ЈЕЗИКУ

\section{Литература}

Браунинг, Р. (2005). Среgњовековни и савремени ірчки језик. Лозница: Карпос.

Brewster, J. (2004). Contet-based language teaching: a way to keep students motivated and challenged? In: IATEFL SIG Newsletter, pp. 26-28.

Будимир, М., Црепајац, љ. (1979). ГTOIXEIA EАЯHNIKA, Основи ірчке ілойолойје. Београд: Научна књига.

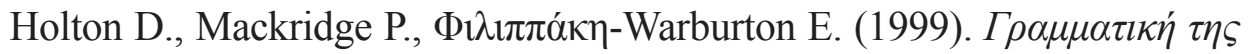

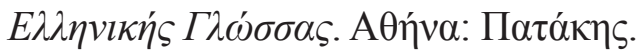

Jovanović, M. (2012). Klasični grčki jezik u savremenoj visokoškolskoj nastavi. U: Approaches and Methods in Second and Foreign Language Teaching. Sarajevo: IBU Publications, str. 379-388.

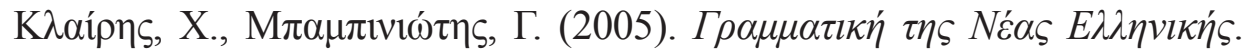

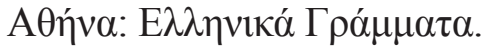

Mackridge P. (1985). The Modern Greek Language: A Descriptive Analysis of Standard Modern Greek. Oxford: OUP.

Meillet, A. (1950). Les dialectes indo-européens. Paris: Librairie Ancienne Edouard Champion.

Rix, H. (1976). Historische Grammatik des Griechischen. Darmstadt: Wissenschaftlichen Buchgesellschaft.

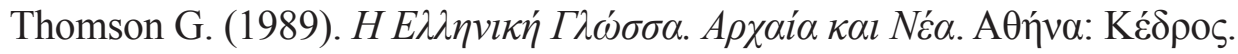

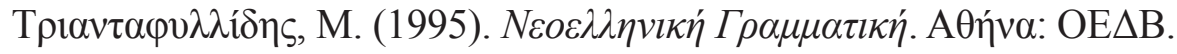

Тријандафилидис, М. (1995). Мала новоірчка ірамайика (превео и приредио Зоран Мутић). Тесалоника: Институт за новогрчке студије Аристотеловог универзитета.

Vulfolk, A., Hjuz, M., Volkap, V. (2014). Psihologija u obrazovanju II. Beograd: Clio.

Warburton I. (1973). Modern Greek Verb Conjugation: Inflectional Morphology in a Transformational Grammar. Lingua 32, pp. 193-226. 
Војкан Б. Стојичић, Ана С. Елаковић Ненадовић

Ana Elaković Nenadović

Vojkan Stojičić

\section{Summary}

\section{THE CONTRASTIVE ANALYSIS OF IMPERFECT FORMS IN CLASSICAL AND MODERN GREEK LANGUAGE - AN INTRALINGUISTIC APPROACH}

When it comes to teaching foreign languages, contrasting language systems achieve better understanding and mastering of certain grammatical categories. Therefore, it is important to point out the importance of making the correlation of linguistic phenomena in the field of phonetics, morphology, syntax and semantics, which simultaneously improves the cognitive abilities of the students and presents the motivating factor in the learning process. In our paper, we shall pay special attention to the ancient heritage that is preserved in the Modern Greek language. Contrasting certain corpus of classical and contemporary forms of verbs in the imperfect tense, we will analyze the similarities and differences in the construction and use of imperfect, as well as its adequate translation in Serbian language.

Key words: contrastive analysis, Classical Greek language, Modern Greek language, imperfect. 